\title{
TEK PARTI YÖNETIMI KURULURKEN MANISA'DA GENEL SEÇIMLER (1923-1931)
}

\author{
Nejdet BİLG $\dot{I}^{*}$
}

\begin{abstract}
Öz
1920 yılında açılan I. TBMM, İstiklal Savaşı'nın ardından seçimle yenilendi. 1923 Nisan'ında alınan yenileme kararının ardından, seçim çalışmalarına başlandı. Bu, tek parti dönemi kurulurken gidilen ilk seçimdir. Manisa bağlamında 1923 milletvekili seçimi, özellikle adayların belirlenmesinde yerelde etkili olan şahısların belirleyici olduğu bir seçimdir. Ülke genelinde yaklaşık 3 ay süren bu seçimler, Manisa'da beş haftada tamamlandı. Manisa bu seçimde Meclis'e 9 milletvekili gönderdi. 1927 milletvekili seçimi, yalnızca CHF adaylarıyla gerçekleştirilen onaylama tarzında bir seçimdir. Ülke genelinde "ikinci seçmen" seçimleri 10 Ağustos'ta, milletvekili seçimleri ise 8 Eylül 1927 'de tamamlandı. Manisa'da ülke genelinden farklı olarak, milletvekili seçimi 2 Eylül günü başladı ve bitirildi. Manisa'dan yine 9 milletvekili seçildi. 1931 genel seçimi normal tarihinden yaklaşık 7 ay önce yapıldı. CHF, 63 seçim çevresinin 22'sinde, bağımsız adaylar için 30 kontenjan ayırdı. 9 milletvekili seçilecek olan Manisa'dan, CHF 8 aday gösterdi, 1 adayın yerini bağımsızlara ayırdı. Manisa'da "ikinci seçmen" seçimi 4-13 Nisan'da gerçekleştirildi. Milletvekili seçimi ise bütün ülkede olduğu gibi 24 Nisan'da gerçekleştirildi. Sonuçta $8 \mathrm{CHF}$ adayı ile bağımsız aday kontenjanından İsmet Paşa ikinci seçmenler tarafından Manisa milletvekili seçildiler.
\end{abstract}

Anahtar kelimeler: Manisa, Seçim, Tek Parti, Milletvekili, Cumhuriyet Halk Fırkası

\begin{abstract}
General Elections in Manisa Which is Established One Party Management (1923-1931)

Established in 1920, the First Grand National Assembly was renewed by election after the Turkish War of Independence. Groundwork for the election was put into place upon the renewal decision in April 1923. This election marks the beginning of the single-party period. Individuals with extensive local influence played a significant role in determining the candidates for the 1923 deputy election in Manisa. Spanning over three months on a national level, elections in Manisa was completed in only five weeks. Manisa sent nine deputies to the Assembly with this election. 1927 deputy election was held only with the CHF candidates, and it was more of an
\end{abstract}

\footnotetext{
* Doç. Dr., Manisa Celal Bayar Üniversitesi, Fen-Edebiyat Fakültesi, Tarih Bölümü, Manisa. E-posta: nejdet.bilgi@gmail.com, ORCID: https://orcid.org/0000-0002-2288-616X

(Makale Gönderim Tarihi: 18.09.2018 - Makale Kabul Tarihi: 04.03.2019)
} 


\section{Nejdet BILGi}

acknowledgment than an election. The "secondary voter" election was concluded on August 10, 1927, and the deputy elections on September 8. Unlike the National election, Manisa started and concluded its deputy election on September 2. Once again, nine deputies were elected in Manisa. The general election of 1931 was held seven months early. CHF reserved 30 seats for independent candidates in 22 out of 63 constituencies. Eight candidates from CHF were running in Manisa, which had a total of nine seats, and one spot was reserved for an independent candidate. The "secondary voter" elections in Manisa were held between April 4 and 13. Deputy election was held on April 24, same as the rest of the country. Eventually, secondary voters elected eight CHF candidates, and İsmet Pasha for the independent seat.

Key words: Manisa, Election, Single-Party, Deputy, CHF

\section{Giriş}

Milli Mücadele'nin ardından 1923 Nisan'ında Türkiye Büyük Millet Meclisi'nin (TBMM) yenilenmesi kararı alınmış ve bu doğrultuda Mayıs ayı başlarında ülke çapında seçim çalışmalarına başlanmıştı. Bu yeni dönemin ilk genel seçimiydi ve seçimler 1908 tarihli seçim kanunu ile birlikte, 3 Nisan 1923 tarihli "Intihab-ı Mebusan Kanun-ı Muvakkati'nin Bazı Mevadını Muaddil Kanun"a göre göre yapılacaktı. Buna göre 18 yaşını tamamlayan her erkek seçim hakkına sahiptir. Müntehib-i evvel, müntehib-i sani veya milletvekili olabilmek için vergi mükellefi olmak şart değildir. ${ }^{1}$ Oy verme işlemi nahiye veya kaza merkezlerinde gerçekleştirilecekti. Önce müntehib-i evveller müntehib-i sanileri belirleyecekti. Daha sonra mebus seçimleri için müntehib-i saniler belirlenen günde kaza, liva veya vilayet merkezlerine giderek oylarını kullanacaklardi. ${ }^{2}$

Seçim kararının alınmasının ardından 8 Nisan 1923 tarihinde, Gazi Mustafa Kemal tarafindan, Anadolu ve Rumeli Müdafaa-i Hukuk Grubu'nun Halk Fırkası'na dönüştürüleceğini belirten bir beyanname yayımladı. Yeni seçimlere, bu firkanın ilkeleri kabul edilebilecek olan, 9 ilkeden oluşan bu beyanname ile girildi. ${ }^{3}$

Seçimlere Müdafaa-i Hukuk Grubu'nun dışında kimlerin katılabileceği açıkça ve resmi olarak belirtilmemekle beraber, dönemin basınında bazı değerlendirmeler yapılmıştır. ${ }^{4}$ Ancak, seçim sürecinde Müdafaa-i Hukuk Birinci Grubu'nun dışında herhangi bir grubun adı geçmemiş̧tir. Buna rağmen, 1923 seçimlerinin tek parti dönemi seçimleri arasında, diğerlerine göre "daha özgür bir ortamda" gerçekleştirilmiş olduğu kanaati vardır. ${ }^{5}$

1927 seçimleri ise Şeyh Sait Ayaklanması, Takrir-i Sükun uygulamaları,

\footnotetext{
${ }^{1}$ Güneş 1991, s. 257-259; Uyar 1999, s. 24; Olgun 2011, s. 11-12.

${ }^{2}$ Güneş 1991, s. 261-264.

${ }^{3}$ Erdoğan 2000, s. 39-41; Hakimiyet-i Milliye, 9 Nisan 1339/1923, s. 1.

${ }^{4}$ Erdoğan 2000, s. 44.

${ }^{5}$ Uyar 1999, s. 24.
} 
Terakkiperver Cumhuriyet Fırkası'nın kapatılması, İzmir suikasti girişimi ve yargılamaları gibi, ülkenin sosyal ve siyasi hayatında derin izler birakan olaylar sonrasında gerçekleştirilmiştir. Bu yüzden aday belirleme süreci ve seçimler, aşırı kontrollü ve Gazi’nin belirleyiciliğinde tamamlanmıştır. 1923 ve 1931 seçimleriyle kıyaslanamayacak kadar, seçmenin belirleyiciliğginin olmadığ bir seçimdir.

1931 Seçimleri ise normal süresinden yaklaşık 7 ay kadar önce, hemen hemen aynı kalan seçim kanunuyla yapılmıştır. Ancak 1931 seçimlerinin de yakın geçmişteki olayların etkisine maruz kaldığı söylenebilir. Yaklaşık 3 ay kadar önce kapanan Serbest Cumhuriyet Fırkası (SCF) ile resmileşen ve resmileşemeyen diğer partilerin, 1930'un sonlarına kadar süren maceraları, bu etkilerin başında gelmektedir. Ayrıca, 1930’un son günlerinde patlak veren Menemen Olayı'nın da -en azından laiklik bağlamında- etkili olduğu yönler bulunabilir. Yine de 1927 seçimlerine göre, seçmenin hareket alanının daha geniş olduğu söylenebilir. Bizzat Gazi'nin isteği ile 22 vilayette 30 mebusluğun bağımsızlar için ayrılmış olması, farkı göstermeye yeterli sayılabilir. Bu tasavvur tahakkuk etmemiş olsa da, en azından basında daha geniş bir tartışma ortamının oluşması ve seçmene kısmen de olsa hareket alanı açmış olması, 1927 seçimlerinden farklı bir ortama işaret etmektedir.

\section{Müntehib-i Sani (İkinci Seçmen) Seçimleri}

Seçim kararından sonra, ister istemez her yerde olduğu gibi Manisa' da da bir siyasi hareketlilik göze çarpmaya başliyor. ${ }^{6}$ Yerel gazeteye bir mülakat veren Müdafaa-i Milliye Vekili Kazım (Özalp) Paşa, seçim çalışmalarının suhuletle yürütüldüğünü, yakında yeni mebusların belirleneceğini, her yerde Müdafaa-i Hukuk adaylarının çoğunluğu kazanacaklarını söylüyor. ${ }^{7}$ Yaklaşan seçimlerin Manisa'daki siyasi hareketliliği artırdığı anlaşılıyor. Nitekim Manisa Türk Ocağı'nın 1 Haziran 1923 tarihindeki seçimlerinde, Mebus Necati Bey, Belediye Reisi Bahri Bey, Dr. Saim Bey ve Müftü Âlim Efendi’nin de yer almaları, ${ }^{8}$ biraz da milletvekili seçimine yönelik olmalıdır.

Yerel basında 2 Haziran'da yayımlanan bir haberde, Manisa dahilinde seçim faaliyetinin başladığı, şimdilik kazalardan nüfus miktarlarının belirlenerek merkeze bildirildiği, Alaşehir ve Akhisar dışındaki kazaların ve Manisa merkez kazasının defterlerinin tamamlandığı ve 2 Haziran'da askıya çıkarılacakları belirtilmektedir. ${ }^{9}$ Bundan bir hafta sonra, 9 ve 12 Haziran

\footnotetext{
${ }^{6}$ Saruhan, 26 May1s 1923.

${ }^{7}$ Saruhan, 26 May1s 1923.

${ }^{8}$ Saruhan, 2 Haziran 1923.

${ }^{9}$ Saruhan, 2 Haziran 1923.
} 


\section{Nejdet BILGI}

tarihlerindeki iki ayrı gazetede yer alan haberlerde, Manisa livasında seçim faaliyetine devam edildiği, şimdilik her kazadan çıkarılacak olan "müntehib-i sani" sayısının belirlenmeye çalışıldığı ve bu çerçevede Haziran'ın sonlarına doğru müntehib-i sani seçiminin tamamlanacağ 1 belirtilmektedir. "Defatir-i Esasiye"nin merkezde 3 Haziran'da asıldığ 1 ve 25 Haziran'da müntehib-i sani seçimlerinin bütünüyle sonuçlanmış olacağı vurgulanmaktadır. Liva merkezine bağlı köylerde ise, “Defatir-i Esasiye”nin 1 Haziran'da asıldı̆̆ 1 ve 23 Haziran'da buralardaki seçimlerin de tamamlanmış olacağı belirtilmektedir. Her iki haberde de, Manisa merkez kazasının 130 müntehib-i sani çıkaracağı yazmaktadır. Müntehib-i sani sayısı belli olan kazalar ise Kasaba/Turgutlu, Kula, Salihli ve Gördes olarak stralanmakta, diğerlerinden söz edilmemektedir. Buna göre Kasaba 53, Kula 59, Salihli 51, Gördes 52 müntehib-i sani (ikinci seçmen) çıkaracaktır. ${ }^{10}$ Aradan onbir gün geçtikten sonra, 21 Haziran'da yayımlanan bir haberde, Manisa seçimleri hakkında biraz farklı bilgi verilmektedir. Bu habere göre, livanın merkezi dışında, yani kazalarda seçim tamamlanmıştır. Tamamlanmak üzere olan Merkez kazanın müntehib-i sani sayısı öncekilerden farklı olarak 140 şeklinde verilmektedir. ${ }^{11}$

İki dereceli bu seçimlerde oy kullanma yöntemi, dönemin yarı resmi gazetesi Hakimiyet-i Milliye'de, özetle şu şekilde izah edilmektedir: Seçim günü her mahallenin müntehib-i evvelleri (birinci seçmenler) mahallenin muhtar, imam ve mahalle meclisi üyesinden ikişer kişi ile, toplu olarak sandığın bulunduğu yere geleceklerdir. Burada oluşturulan "heyet-i teftişiye" huzurunda oylarını sandıklara atacaklardır. ${ }^{12}$

Manisa merkezinin müntehib-i sani seçimleri, muhtemelen benzer bir yöntemle, 26 Haziran 1923 tarihinde gerçekleştirilmiştir. Saruhan gazetesinin haberine göre, Manisa müntehib-i sani seçimleri "yüksek tezahürat-ı milliye ile” yapılmıştır. Seçim günü erkenden hazırlanan süslü faytonlar, bayrakla örtülü seçim sandıklarıyla şehirde dolaştırılmış ve her seçim sandığ 1 , halkın sevinç gösterileri arasında, ilgililer tarafından saygıyla teslim alınmıştır. Belediye Reisi Bahri, her seçim dairesi halkına, seçimin değeri ve öneminden söz eden, "klsa fakat ruhlu" konuşmalar yapmıştır. Haberin devamında, oyların sayıldığı ve Müdafaa-i Hukuk mensubu müntehib-i sanilerin çoğunlukla kazandıklarının anlaşıldığ 1 belirtilmektedir. Ardından, mebus seçimlerinin de aynı şekilde sonuçlanacağından şüphe edilmediği vurgulanmaktadır. 27 Haziran akşamı oyların sayımı yapılmış ve şehirdeki 6 seçim dairesinde seçilen 33 müntehib-i

\footnotetext{
${ }^{10}$ Saruhan, 9 Haziran 1923; Türk Sesi, 12 Haziran 1923, s. 3. Her iki gazetede de, "bir Haziran” yerine sehven "bir Mayıs" yazılıdır.

${ }^{11}$ Türk Sesi, 21 Haziran 1923, s. 3.

${ }^{12}$ Hakimiyet-i Milliye, 18 Haziran 1339/1923, s. 2.
} 
saninin isimleri açıklanmıştır. ${ }^{13}$

Bu sonuçlara göre, Manisa merkezinde 33 müntehib-i sani belirlenmiş oluyordu. Toplam sayı 140 olduğuna göre, müntehib-i sanilerin çoğunun merkez kazaya bağlı nahiye ve köylerden seçileceği anlaşılmaktadır. Saruhan livasının bu seçimlerdeki toplam müntehib-i sani sayısı en az 611 olmalıdır. Çünkü seçilen mebusların biyografilerinde aldıkları belirtilen en fazla oy sayısı budur. $^{14}$ Oy kullanamayanların ve diğer adaylara oy verenlerin olabileceği dikkate alındığında, bu sayının en az 611 olduğu rahatlıkla söylenebilir.

\section{Mebus (Milletvekili) Seçimleri}

Manisa'da müntehib-i sani seçimleri sürerken, Hakimiyet-i Milliye gazetesi 20 Haziran'da tahmini Saruhan adayları olarak şu altı ismi açıkladı: 1Saruhan Mebusu Reşad, 2-Posta ve Telgraf Müdir-i Umumisi Sabri, 3Darülfünun Müderrislerinden Mustafa Fevzi, 4-Pehlivanzade Edhem, 5-İzmir Maarif Müdir-i Sabıkı Vasıf, 6-Dava vekili Abidin. Aynı haberde, Yakub Kadri'nin 5 milletvekili çıkaracak olan Mardin'in 11 adayı arasında yer alıyordu. $^{15}$ Aynı adaylar, aynı tarihte Tanin gazetesinde de yer aldilar. ${ }^{16}$ İzmir'de yayınlanan Türk Sesi gazetesi ise, ayn1 isimleri "Müdafaa-i Hukuk Grubu tarafindan ilan olunan Saruhan livası mebus namzedleri” olarak duyurdu. ${ }^{17} \mathrm{Bu}$ arada, ertesi gün yayımlanan bir haberde, Saruhan'da "Defatir-i Esasiye"de 6 mebus ç1karacağ1 belirtilmesine rağmen, nüfusa göre hesaplandığında 7 mebus çıkarılması gerektiğinden, ilgili yerlere başvurulduğu belirtilmektedir. ${ }^{18} 21$ Haziran tarihli bir İstanbul gazetesi, yayımlanan listelere bir isim daha ekliyordu: “İkdam Gazetesi Muharriri Yakub Kadri Bey."19 23 Haziran tarihli Tanin ve 24 Haziran tarihli Vakit gazeteleri ise, daha önceki 6 kişilik listeye, yedinci olarak İstanbul Gümrükleri Dava Vekili Kemal Bey’in ismini eklemişlerdir. ${ }^{20} 25$ Mayıs'ta Hakimiyet-i Milliye Saruhan'ın milletvekili

\footnotetext{
13 “Manisa'da İntihabat”, Saruhan, 30 Haziran 1923.

${ }^{14}$ En düşük oy 558, en yüksek oy 611'dir. Öztürk 1995a, s. 667, 670-671, 673-674, 676, 679, 681.

${ }^{15}$ Hakimiyet-i Milliye, 20 Haziran 1339/1923, s. 1. Bir gün önceki bir İzmir gazetesinde "İzmir Maarif Müdir-i Sabıkı Vasıf Beyefendi'nin Müdafaa-i Hukuk Grubu'nca Saruhan Livası mebus namzedleri meyanında gösterileceği mevsukan ve memnuniyetle haber alınmışdır" haberi yer almıştır. Türk Sesi, 19 Haziran 1339/1923, s. 2.

${ }^{16}$ Tanin, 20 Haziran 1339/1923, s. 1.

${ }^{17}$ Türk Sesi, 20 Haziran 1339/1923, s. 2.

${ }^{18}$ Türk Sesi, 21 Haziran 1923, s. 3.

${ }^{19}$ Akşam, 21 Haziran 1339/1923, s. 3.

${ }^{20}$ Tanin, 23 Haziran 1339/1923, s. 1; Vakit, 24 Haziran 1339/1923, s. 1. I. Dönem Saruhan mebusu Celal [Bayar] ve Mustafa Necati Beyler, II. Dönem için İzmir'den aday gösterilmeleri üzerine, Saruhanlılara teşekkür telgrafı çekmişlerdir. Türk Sesi, 19 Haziran 1339/1923, s. 3;
} 
sayısının 7 olarak tespit edildiğini duyurdu ${ }^{21}$ ve yedinci adayın da, "İstanbul Gümrükleri Hukuk Müşaviri Dava Vekili Manisalı Kadızade Kemal Bey” olduğunu yazd1. ${ }^{22}$ Saruhan mebus adaylığ rekabetinin hangi düzeyde olduğunu gösteren bir haber, İzmir'de yayın yapan Ahenk gazetesinde yer aldı. Gazetenin seyyar muhabirinin haberi şu şekildedir: "Manisa'da intihabat meselesi münakaşatı mucib olmaktadır. Manisa ve havalisi ahalisi alelumum Müdafaa-i Hukuk'un göstereceği namzedlere rey vermek kararında olduklarından memleketleriyle hiç alakadar olmayan ve kendilerine büsbütün yabancı bulunan bazı zevatın namzed gösterilmemesini Ankara'dan rica etmişlerdi. Gösterilecek namzedlerin arasında Manisalıların arzularina tevafuk etmeyen bazı zevat bulunduğu şayi olunca ahali tarafindan müntehib zevat telgrafla Ankara'ya müracaat eylemişlerdir. Ve gösterilecek namzedlerin her halde Manisalılarca temiz tanınmış olanlardan bulunmasını istemişlerdir.

Manisalılar, Müdafaa-i Hukuk'dan olan, Abidin, Reşad, Mustafa Fevzi, Posta Müdir-i Umumisi Kasabalı Sabri, Vakit gazetesi sahibi Hakkı Tarı, Hacı Edhem, Kemal Beyleri ve bir de Yakub Kadri Bey’i mebus yapmak istiyorlar ve bunda israr ediyorlar. Esasen Müdafaa-i Hukuk bu zevatdan Abidin, Reşad, Mustafa Fevzi, Sabri, Hacl Edhem Beyleri namzed gösteriyor. Şimdi Manisalılar Kemal, Hakkı Tarı, Yakub Kadri Beyleri feda etmek istemiyorlar ve Ankara'dan bu zevatdan listenin ikmalini istirham ediyorlar. Bugünkü tahkikatım bu merkezdedir. Ahali telgraf çekib duruyorlar.,"23

Haberde geçen, "Esasen Müdafaa-i Hukuk bu zevatdan Abidin, Reşad, Mustafa Fevzi, Sabri, Hacı Edhem Beyleri namzed gösteriyor” ifadesi, burada anılan 5 ismi vazgeçilmez olarak sunuyor. Geriye üç isim kalıyor: Kemal, Hakkı Tarık ve Yakup Kadri. Bir de bu haberde adı geçmeyen, Vasıf Bey var. Dolayısıyla Müdafaa-i Hukuk Grubu merkezinin, 5’i yerelden destekli bu listeyi, 9'dan 7'ye indirmede sıkıntı yaşayacağı anlaşılıyor. Nitekim Ahenk'in haberinin devamında, Manisa'daki seçim rekabetine işaret eden bazı bilgiler de yer alıyor. Buna göre Müftü Alim Efendi ile Aza Halid Bey, Müdafaa-i Hukuk yönetiminden istifa etmişlerdir. ${ }^{24}$ Haberin son kısmında, Manisa kamuoyunun kendi livaları dahilinde yetişen simaları diğerlerine tercih ettiği vurgulanmaktadır. Bu ifade, listenin büyük ölçüde bu kriterlere uyan 5 kişilik kısmına karşılık gelmektedir. Diğer 4 kişinin 3'ü, yani Kemal, Hakkı Tarık ve Yakup Kadri Manisalı olmakla beraber, hayatlarını Manisa dışında geçirmektedirler. Dördüncü isim olan Vasıf Bey ise İzmirli. Belki de bu yüzden,

\footnotetext{
Hakimiyet-i Milliye, 22 Haziran 1339/1923, s. 3.

${ }^{21}$ Hakimiyet-i Milliye, 25 Haziran 1339/1923, s. 2.

${ }^{22}$ Hakimiyet-i Milliye, 25 Haziran 1339/1923, s. 1.

23 "Manisa' da İntihabat", Ahenk, 22 Haziran 1339, s. 3.

24 “Manisa'da İntihabat", Ahenk, 22 Haziran 1339, s. 3.
} 
Ahenk'in haberinde adı anılmamaktadır.

Ahenk gazetesi, haberi verdikten sonra, altına dikkat çekici şu yorumu eklemektedir: "Muhabirimizin işaratından anlaşıllyor ki Manisalılar Müdafaa-i Hukuk'un namzedlerine rey vermekde müttefikdirler. Yalnız kendi yetişdirdiklerini -Müdafaa-i Hukuk'a sadık kaldıklarına kani oldukları takdirde- tercih etmek istiyorlar. Hususiyle Hakk Tarlk gibi nezih ve faziletli bir oğulların ileri sürüyorlar. Hakkı Tarık hiç şübhe yok ki Manisa'nın bihakkın medar-l iftihar olan faziletli bir gençdir. Bu faziletli kardaşın Müdafaa-i Hukuk'a merbutiyeti de sözle değil fiil ile müeyyed ve âlidir. Bunu bizim gibi Ankara intihabat encümeni de takdir eder ve bilir. Pek mütevazı olan Hakkı Tarık'ın hidematını yâda, lüzum görmüyoruz. Çünkü bu aziz kardaşın evsafi arasında kuvvetli bir yer tutan tevazuunu rencide etmiş oluruz.

Madem ki halk, kendi oğulları olan Hakkı Tarık'ı, Kemal Bey'i ve sair oğullarından birini istiyor ve madem ki bu nezih kardaşlar da Müdafaa-i Hukuk umdelerini kanaat edinmişlerdir ve Müdafaa-i Hukuk'dandırlar, o halde zaten namzedlerin kesret-i azimesi üzerinde temerküz eden budur. Grup ve halk temayülatınin bu arzu ile de tetvicine hiçbir mani yokdur. Bize kalırsa bu cihetin iltizamı iyidir. Biz bitaraf bir münekkid sifatıyle bunu böyle düşünüyoruz.," 25

Ahenk’e göre, Manisalılar Müdafaa-i Hukuk adaylarına oy verecekler ve kendi yetiştirdikleri kişileri tercih edeceklerdir. Bu vurgu, haberdeki 5 kişilik listeye yapılmaktadır. Milletvekili sayısı 7 olacağına göre, ikisinin de halkın "kendi oğulları"ndan Hakkı Tarık ve Kemal Beylere yönlendirme yapıldı̆̆g açıktır. Yorumda, Yakup Kadri'den hiç söz edilmemesi de dikkat çekiyor. Ahenk'in Yakup Kadri'yi, "sair oğullarından biri" olarak anmakla yetindiği anlaşı1ıyor.

Yakup Kadri, yıllar sonra kaleme aldığı hatıralarında, bu meseleye değinme ihtiyacını hissetmiştir. ${ }^{26} 1923$ milletvekili seçimlerinde, Saruhan'a ait bazı aday listelerinde adı geçirilen Yakup Kadri, isminin "şirretçe bir muhalefetle" karşılandığını, adaylığından rahatsız olanların zamanında Erzurum ve Sivas kongrelerinin prensiplerine yeterince ilgi göstermeyen, Yunan istilası karşısında Ankara'ya gelmek yerine, nerelere gittikleri belli olmayan ve zaferde payları varmış gibi "külah kapmağa" çalışan kişiler olduğunu belirtiyor ve şöyle devam ediyor: "Fakat, ne çare ki, Rum kundakçılar tarafinda baştan başa yakılıp yıkılmış Manisa'nın külleri ve molozları içinde bile gözlerini siyasi ihtiraslar bürüyen kimselere meram anlatmak mümkün olamamıstl. Bunlar

\footnotetext{
25 “Manisa'da İntihabat”, Ahenk, 22 Haziran 1339, s. 3.

${ }^{26}$ Yakup Kadri'nin konuyla ilgili anıları ilk kez 1968 yılında yayımlanmıştır. Karaosmanoğlu 1984, s. 13.
} 


\section{Nejdet BILGi}

daha o zamandan beri birtakım zafer ganimetleri paylaşmağa çımış̧lardı. Hepsi itişe kakışa biribirinin önüne geçmeye çabalıyor; kimi de gözünü daha ilerilere dikiyordu.

Nitekim, Manisa'dan ayrllırken benimle konuşan adam çok zaman geçmeyecek, belediye reisi, onu müteakip yeni kurulan Müdafaa-i Hukuk başkanı olacak ve mebus seçimleri gelip çattı̆̆ vakit benim aleyhime türlü tezvirler çevirmekten bile geri kalmayacak, Ankara'da Merkez Seçim Kurulu'na çektirdiği bilmem kaç yüz imzalı 'istemezük' telgraflarlyla meramına erecekti. Yani beni ve benimle beraber Vakit gazetesi sahiplerinden Hakkı Tarlk (Us)'u Manisa milletvekili adayları listesinden çıkartıp kendine yakın bildiği kimseleri getirmek yolunu bulacaktt. Bunlar da Meşrutiyet devrinin küçük bir maliye memurlarından biriyle şeriat hukukçusu bir hoca efendiden başka kimseler değillerdi., ${ }^{27}$

Yakup Kadri'nin isimlerini vermediği belediye başkanı Bahri (Sarıtepe), "küçük bir maliye memur"u olarak andığı milletvekili Mehmet Reşat (Kayalı) ve "şeriat hukukçusu bir hoca efendi" olarak andığı milletvekili ise Mustafa Fevzi (Sarhan)'dir. ${ }^{28}$ Oysa, dönemin gazetelerinden aktardığımız tartışmalarda, son iki isimle ilgili bir çekinceden söz edilmemektedir. Yakup Kadri’nin listeye dahil edilen bu isimlere ve bu isimlerin listede yer almasını sağladığg anlaşılan Belediye Reisi Bahri'ye mesafeli olduğu anlaşılmaktadır.

Aday listeleri bu tartışmaların gölgesinde, Hakimiyet-i Milliye'nin 20 ve 25 Haziran'da yayımladığ 1 listedeki 7 adaydan oluşacak ve seçimlere de bu şekilde gidilecektir. Bu çerçevede Yakup Kadri'ye Mardin, ${ }^{29}$ Hakkı Tarık'a da Giresun ${ }^{30}$ listelerinde aday olarak yer verilecektir.

Basında yer alan haberlere göre, Saruhan livasının bazı kazalarında müntehib-i sani seçimleri merkezden önce tamamlanmış ve mebus seçimleri de bu yüzden erken yapılmıştır. Manisa merkezinde müntehib-i sani seçimleri 27 Haziran akşamı tamamlanmışken, Vakit gazetesinin 25 Haziran tarihli haberinde, Kasaba ve Salihli'de müntehib-i sanilerin müttefikan Müdafaa-i Hukuk adaylarına oy verdikleri belirtilmektedir. ${ }^{31}$ Aynı gazetenin Gördes hususi muhabiri, 27 Haziran'da Müdafaa-i Hukuk adaylarının oybirliği ile

\footnotetext{
${ }^{27}$ Karaosmanoğlu 1984, s. 36-39.

${ }^{28} 1876$ Akhisar doğumlu olan Mustafa Fevzi Efendi, Manisa ve İstanbul'da medrese eğitimi gördü. Hukuk Mektebini birinci olarak bitirdi. Hukuk ve Nüvvab mekteplerinde hocalık yaptı. 1912'de Manisa mebusu seçildi. 1923'den 1933’te ölümüne kadar Manisa milletvekilliği, 1923-1924 yıllarında Șeriyye Vekilliği yaptı. Öztürk 1995a, s. 678-679.

${ }^{29}$ Hakimiyet-i Milliye, 20 Haziran 1339/1923, s. 1. Yakub Kadri 294 oy alarak, üçüncü sıradan Mardin milletvekili seçilmiştir. Hakimiyet-i Milliye, 2 Temmuz 1339/1923, s. 1.

${ }^{30}$ Hakimiyet-i Milliye, 5 Temmuz 1339/1923, s. 1; Türk Sesi, 6 Temmuz 1339/1923, s. 2.

${ }^{31}$ Vakit, 25 Haziran 1339/1923, s. 2.
} 
seçildiklerini bildirmiştir. ${ }^{32}$ Yani, 27 Haziran akşamı Manisa merkezinde müntehib-i sani seçimleri tamamlanırken, Gördes'te milletvekili seçimleri sonuçlanmıştır. Hakimiyet-i Milliye'nin 28 Haziran'da verdiği habere göre, Salihli, Turgutlu ve Soma kazalarında milletvekili seçimleri tamamlanmış ve Müdafaa-i Hukuk adayları kazanmışlardır. ${ }^{33}$ Aynı gazetenin 3 Temmuz tarihli haberine göre, Alaşehir, Demirci ve Akhisar kazalarında da Müdafaa-i Hukuk adaylarına oy verilmiştir. ${ }^{34}$ Bir gün sonraki Türk Sesi gazetesi, Saruhan livasının merkez dışındaki kazalarında mebus seçimlerinin, ittifakla Müdafaa-i Hukuk adaylarının seçilmeleri ile sonuçlandığını, merkezdeki seçimlerin de 4 Temmuz günü yapılacağını belirtiyor. ${ }^{35}$ Nihayetinde, Saruhan livasında Müdafaa-i Hukuk Grubu adaylarının, oybirliğine yakın bir çoğunlukla seçimleri kazandıkları, 8 Temmuz tarihli Türk Sesi gazetesiyle duyurulmuştur. Gazete seçimleri kazanan mebusların isimlerini şöyle vermektedir: "Sabık Nafia Vekaleti Vekili Reşad, Darülfünun müderrislerinden Mustafa Fevzi, sabık mebuslardan Posta ve Telgraf Müdir-i Umumisi Sabri, Sabık İzmir Maarif Müdiri Vasıf, Dava Vekili Abidin, Pehlivanzade Edhem, İstanbul Gümrükleri Hukuk Müşaviri Menemenlizade Kemal Bey ve Efendiler." Saruhan seçimlerinin son bulduğu haberi, bir gün sonra da Anadolu Ajansı'na (AA) dayalı olarak Hakimiyet-i Milliye'de yer almıştır. Seçilen 7 milletvekilinin isimleri de aynı şekilde verilmiştir. $^{36}$

1923 seçimlerini kazanarak TBMM II. Döneminde Saruhan milletvekili olanların kaçar oyla seçildikleri gazetelerde yer almamıştır. TBMM Arşivi'nden derlenerek oluşturulan biyografilerindeki bilgilere göre, aldıkları oylar sırasıyla şu şekildedir: Kemal Bey 611, Abidin Bey 607, Ethem Bey 606, Sabri Bey 603, Mustafa Fevzi Efendi 587, Reşat Bey 591 ve Vasıf Bey 580. ${ }^{37}$

Saruhan/Manisa'da 1923 milletvekili seçimlerinin 7 Temmuz'da tamamlandığı anlaşılıyor. Ancak, ülke genelindeki durum bir hayli farklılık göstermektedir. Hakimiyet-i Milliye’nin haberine göre, 1923 genel seçimlerine ilk başlayan liva Çanakkale olmuştur. Haberde, Çanakkale livasının 21 Mayıs 1923 Pazartesi günü müntehib-i sani seçimlerine başlayarak birinciliği kazandığı vurgulanıyor. ${ }^{38}$ Müntehib-i sani ve ardından milletvekili seçimlerini

\footnotetext{
${ }^{32}$ Vakit, 28 Haziran 1339/1923, s. 2.

${ }^{33}$ Hakimiyet-i Milliye, 28 Haziran 1339/1923, s. 1.

${ }^{34}$ Hakimiyet-i Milliye, 3 Temmuz 1339/1923, s. 1.

${ }^{35}$ Türk Sesi, 4 Temmuz 1339/1923, s. 2.

${ }^{36}$ Hakimiyet-i Milliye, 9 Temmuz 1339/1923, s. 1; Haber ertesi gün İstanbul gazetelerinden Tanin'de de yer almıştır (10 Temmuz 1339/1923, s. 2).

${ }^{37}$ https://www.tbmm.gov.tr/eyayin/GAZETELER/WEB/MAZBATALAR/TBMM/d02/SM_372_1 2.pdf; Öztürk 1995a, s. 667, 670-671, 674, 676, 679, 681.

${ }^{38}$ Hakimiyet-i Milliye, 22 Mayis 1339/1923, s. 1.
} 


\section{Nejdet BILGi}

tamamlayan ilk seçim çevresi ise Biga livası olmuştur. Hakimiyet-i Milliye'nin 8 Haziran tarihli haberine göre, ilk sonuç olarak belirtilen Biga sancağ seçimlerinin, ${ }^{39} 7$ Haziran 1923 tarihinde tamamlandığ 1 anlaşılmaktadır. Seçim sonuçlarının en son alındığı yerler ise Ordu, Giresun ve Trabzon'dur. Hakimiyet-i Milliye gazetesinden tespit edebildiğimiz kadarıyla, Ordu livası seçimleri 8 Ağustos'ta ${ }^{40}$, Giresun livası seçimleri 12 Ağustos'ta $^{41}$ ve Trabzon vilayeti seçimleri de 15 Ağustos'ta ${ }^{42}$ tamamlanmıştır. Dolayısıyla 1923 genel seçimlerinde, seçim süreci 87 gün sürmüştür. Bu da seçimlerin yaklaş1k üç aylık bir zaman dilimine yayıldığını göstermektedir.

\section{Müntehib-i Sani (İkinci Seçmen) Seçimleri}

Yeni Türk devletinin ikinci genel seçimi 1927 yılında yapıldı ve TBMM III. Dönemi bu seçimler sonucunda oluştu. 26 Temmuz tarihli bir habere göre, mebus seçimleri bu kez ülkenin her yerinde aynı gün yapılacaktır. ${ }^{43} 27$ Temmuz'da Dahiliye Vekili Cemil Bey, mebus adaylarının belirlenme işleminin bitmek üzere olduğunu söylemiştir. ${ }^{44}$

1927 Seçimlerinin en merak edilen taraflarından birisi müstakil yani bağımsız aday meselesidir. Nitekim gazetelerde müstakil adaylara ilişkin haberler yer almaktadır. Bu haberler üzerine bir yazı kaleme alan Hizmet gazetesi başyazarı Zeynel Besim, CHF'nin karşısına müstakil aday çıkmanın sadece firkaya değil aynı zamanda "hürriyete, fazilete, mukaddes gayeye ve inkılaba karşı cephe almak" anlamına geldiğini yazmaktadır. Seçilmenin seçmek gibi medeni bir hak olmasına rağmen, bunun bir amaca yönelik olması gerektiğini vurgulayan Z. Besim, "Gazi asırların çok güçlükle yetişdirdiği nevadirdendir. Onun gördüğ̈nü herkes görebilseydi dünyada herkes bir dahi, herkez bir peygamber olurdu" diyerek, müstakil adaylığı kendini Türk gençliğinden daha mükemmel zanneden zavallılar olarak görmektedir. ${ }^{45}$

Temmuz sonlarına doğru seçimlere ilişkin bir haberde, her yerde "Defatir-i Esasiye"nin düzenlendiği ve ask1 süreci tamamlandığ i için,

\footnotetext{
${ }^{39}$ Hakimiyet-i Milliye, 8 Haziran 1339/1923, s. 1.

${ }^{40}$ Hakimiyet-i Milliye, 15 Ağustos 1339/1923, s. 1.

${ }^{41}$ Hakimiyet-i Milliye, 13 Ağustos 1339/1923, s. 2. Türk Sesi, 14 Ağustos 1339/1923, s. 1'de ayn1 haber, “Ankara 13 A ğustos muhabir-i mahsusumuzdan” denilerek veriliyor.

${ }^{42}$ Hakimiyet-i Milliye, 15 Ağustos 1339/1923, s. 1; Hakimiyet-i Milliye, 17 Ağustos 1339/1923, s. 1. Haber, Anadolu Ajans1 17 Ağustos kaynaklı olarak, Türk Sesi, 18 Ağustos 1339/1923, s. 2 'de de yer aliyor.

${ }^{43}$ Hizmet, 27 Temmuz 1927, s. 2.

${ }^{44}$ Hizmet, 28 Temmuz 1927, s. 2.

45 Zeynel Besim, “Müstakil Namzedler”, Hizmet, 28 Temmuz 1927, s. 1.
} 
peyderpey müntehib-i sani seçimlerinin başladığı belirtilmektedir. ${ }^{46}$ Manisa ve kazalarındaki seçimlere ilişkin haberlerin de 1927 Temmuz sonlarından itibaren yayınlanmaya başladığı görülüyor. Nitekim 27 Temmuz tarihli bir haberde, Demirci'de seçim için yoğun bir faaliyet olduğu, müntehib-i evvellerin defterlerinin kasabanın uygun yerlerine ve bütün köylere asıldı̆̆ 1 bildirilmektedir. ${ }^{47}$ Anadolu gazetesinin 28 Temmuz tarihli haberine göre, Manisa'da seçim hazırlıkları sürmektedir. Bu kez seçimlerde 9-10 mebus çıkarması tahmin edilmektedir. ${ }^{48}$ Anadolu Ajansı'nın 28 Temmuz tarihli haberine göre, Akhisar'da müntehib-i sani seçimleri tamamlanmıştır. CHF adayları müttefikan seçilmişler ve 98 müntehib-i sani çıkmıştır. ${ }^{49}$ Hizmet'in 2 Ağustos tarihli haberine göre, Soma seçimleri düzenli bir şekilde sürmektedir. Mahalle ve köylere asılan intihabat defterleri 26 Temmuz Salı günü indirilmiş ve Heyet-i Teftişiye'ye hiç itiraz olmamıştır. Soma kazasının merkeziyle beraber 16 şubeye ayrıldığ 1 ve müntehib-i sani seçimlerine 1 Ağustos'ta başlanacağı belirtilmektedir. Soma kazasında Defatir-i Esasiye’ye göre erkek nüfus miktarı 10.335 olduğu için 45 müntehib-i sani çıkaracağı da ilave edilmektedir. ${ }^{50}$ Demirci'de de 1 Ağustos'ta müntehib-i sani seçimlerine başlandığ 1 belirtilmektedir. ${ }^{51}$ Kula'dan alınan habere göre, 1 Ağustos'ta müntehib-i sani seçimleri yapılmıştır. Seçimlerde CHF adaylarından 67 müntehib-i sani ittifakla seçilmişlerdir. ${ }^{52}$ Kırkağaç kazasında müntehib-i sani seçimleri 2 Ağustos'ta tamamlanmıştır. Toplam 50 müntehib-i sani çıkaran Kırkağaç'ta, oybirliği ile CHF adayları seçilmiştir. ${ }^{53}$ Turgutlu'dan Belediye Reisi Nuri'nin verdiği bilgiye göre, müntehib-i sani seçimleri olağanüstü boyutta tezahüratla gerçekleştirilmiş ve 3 Ağustos günü tamamlanmıştır. Seçimleri CHF'nin gösterdiği 80 aday ittifakla kazanmıştır. ${ }^{54}$ Soma'dan verilen bilgiye göre, merkez kaza ve köylerdeki müntehib-i sani seçimleri 6 Ağustos'ta tamamlanmıştır. Seçimleri 45 CHF adayı kazanmıştır. ${ }^{55} 3$ Ağustos'ta verilen habere göre 31 Temmuz'da Manisa'da müntehib-i sani seçimlerine başlanmıştır. Heyet-i Teftişiye reisi ve azaları oy sandıklarını arabalarla seçim merkezlerine götürmüşlerdir. Merkez kazaya bağlı köylerde müntehib-i sani seçimleri 2 veya 3 Ağustos günü başlayacaktır. Kula ve Akhisar kazalarında

\footnotetext{
${ }^{46}$ Hizmet, 29 Temmuz 1927, s. 2.

${ }^{47}$ Rüşdü Ertuğrul, "Demirci Muhabirimizden”, Hizmet, 27 Temmuz 1927, s. 3.

${ }^{48}$ Anadolu, 28 Temmuz 1927, s. 1.

${ }^{49}$ Hizmet, 29 Temmuz 1927, s. 1.

${ }^{50}$ Doğan, "Soma Mektubu İntihabat Hareketleri”, Hizmet, 2 Ağustos 1927, s. 2.

${ }^{51}$ Hizmet, 3 Ağustos 1927, s. 2; Anadolu, 3 Ağustos 1927, s. 2.

${ }^{52}$ Anadolu, 2 Ağustos 1927, s. 2.

${ }^{53}$ Anadolu, 4 Ağustos 1927, s. 1.

${ }^{54}$ Hizmet, 4 Ağustos 1927, s. 1; Anadolu, 4 Ağustos 1927, s. 1.

${ }^{55}$ Hizmet, 7 Ağustos 1927, s. 1.
} 


\section{Nejdet BILGi}

oybirliği ile CHF adayları müntehib-i sani seçilmişlerdir. Müntehib-i sani seçimlerine başlanması münasebetiyle CHF vilayet idare heyeti bir beyanname yayınlamıştır. Haberin devamında Manisa șehir merkezindeki 8 intihab dairesinde seçilen 40 müntehib-i saninin isimleri verilmektedir. ${ }^{56}$ Alaşehir müntehib-i sani seçimleri 3 Ağustos'ta son bulmuş olup, seçilen müntehib-i sani sayıs1 $73^{\prime}$ tür. ${ }^{57}$ Soma merkez ve köylerinde seçimler 6 Ağustos'ta tamamlanmış ve CHF'li olan 45 müntehib-i saninin tamamı kazanmıştır. ${ }^{58}$ Salihli'de 1 Ağustos'ta başlayan müntehib-i sani seçimlerinde, halkın oybirliği ile CHF adaylarına oy kullandığ 1 belirtilmekle beraber sonuçtan söz edilmemektedir. ${ }^{59}$ Anadolu 8 Ağustos'taki bir haberinde de, Salihli'de hala müntehib-i sani seçimlerinin tamamlanmadığını, kazanın önceki devreye göre bu kez 15 artarak, toplam 62 müntehib-i sani çıkaracağını belirtmektedir. ${ }^{60}$ Oysa bir gün önceki Hizmet'te, Salihli'de seçimlerin hem kaza merkezinde ve hem de 14 şubede tamamlanmış olduğu ve tümü CHF adayı olan 62 müntehib-i saninin seçildiği haberi verilmektedir. ${ }^{61} 10$ Ağustos tarihli bir haberde, aralarında Manisa'nın Eşme ve Gördes kazalarının bulunduğu kazalarda müntehib-i sani seçimlerini firka adaylarının kazandığ 1 belirtilmektedir. ${ }^{62}$ Ancak sayı verilmemektedir. Eşme, Gördes ve Manisa merkez kazasının köyleri hariç, vilayet ölçeğinde

\footnotetext{
56 "Manisa Vilayeti'nde İntihabat”, Anadolu, 3 Ağustos 1927, s. 1-2. Bu müntehib-i sanilerin isimleri şöyle verilmektedir: "Birinci Daire: 1-Vali Nusret Bey, 2-Müftü Alim Efendi, 3Hapishane Müdürü Hafiz Mehmed Efendi, 4-Tüccardan Müslim Efendi, 5-Manifaturacı Çipilzade Hüseyin Efendi. İkinci Daire: 1-Şeyh Mehmed Emin Efendi, 2-Hacı Ail Efendizade Ali Bey, 3-Tüccardan Giridli Selim Bey, 4-Belediye Başkatibi Hilmi Efendi. Üçüncü Daire: 1Zürradan Hafiz Hüseyin Efendi, 2-Giridi Sami Bey, 3-Uncu Zekeriya Efendi, 4-Sadık Efendioğlu Hafiz Mehmed Efendi, 5-Esvabcızade Hafiz Mustafa Efendi. Dördüncü Daire: 1Urgancizade Hacı Hafiz Mustafa Efendi, 2-Hacl Arifzade Salim Efendi, 3-Hacizade Ahmed Efendi, 4-Nalbandoğlu Ali Bey, 5-Tahir Paşazade Bahri Bey, 6- Keresteci Raşid Efendi. Beşinci Daire: 1-Hacı Mahmud Beyzade Kani Bey, 2-Müftüzade Kamil Bey, 3-Tüccardan Hulusi Can Bey, 4-Menemenlizade Kemal Bey, 5-Sarraf Ihsan Bey, 6-Defterdar Raşid Bey. Altıncı Daire: 1-Sihhiye Müdir-i esbakı Saim Bey, 2-Faruk Cevdet Bey, 3-Bakırlizade Halid Efendi, 4-Karaosmanzade Abbas Bey, 5-Şişeci Necmeddin Bey. Yedinci Daire: 1-Tüccardan Haşimzade Tevfik Bey, 2-Külahdaşzade Riza Bey, 3-Muytabzade Hasan Bey, 4-Sami Efendizade Muhtar Efendi, 5-Demircizade Hacı Ahmed Efendi. Sekizinci Daire: 1-Zürradan Hafiz Cemal Efendi, 2-Ger Alizade Ahmed Efendi, 3-Tatlicızade Hilmi Efendi, 4-Fabrikatör Ismet Bey.

${ }^{57}$ Anadolu, 4 Ağustos 1927, s. 2.

58 Hizmet, 7 Ağustos 1927, s. 1. Ancak 10 Ağustos'ta yayınlanan listede 43 kişinin adı bulunmaktadır. "Soma'da İntihabat", Hizmet, 10 Ağustos 1927, s. 3.

${ }^{59}$ Anadolu, 3 Ağustos 1927, s. 2.

${ }^{60}$ Uygur Tekin, "Salihli Haberleri”, Anadolu, 8 Ağustos 1927, s. 2.

${ }^{61}$ Er-Tunç, "Salihli Haberleri”, Hizmet, 7 Ağustos 1927, s. 3. Haberde müntehib-i sani sayısının daha önce 51 olduğu belirtilmektedir.

${ }^{62}$ Hizmet, 10 Ağustos 1927, s. 2.
} 
gazete haberlerinden derlendiği kadarıla, 515 müntehib-i sani seçildiği anlaşılmaktadır. Manisa vilayetinin toplam müntehib-i sani sayısı yaklaşık bir sonra yapılan mebus seçimleri ile ilgili haberlerde yer alacaktır. Buna göre vilayetin müntehib-i sani sayıs1 831'dir. Bunların 20'si mazeretleri dolayısıla seçime katılamamışlardır. ${ }^{63} \mathrm{Bu}$ nedenle kullanılan oy sayısı 811 olmuştur. Nitekim seçilen milletvekillerinin hepsinin biyografilerinde, 811 oy aldıkları belirtilmektedir. ${ }^{64}$

\section{Mebus (Milletvekili) Seçimleri}

Müntehib-i sani seçimlerinin başladığ tarihlerde, mebus adaylığ başvurularının da başladığı anlaşılmaktadır. Hatta 28 Temmuz tarihli bir habere göre, şimdiye kadar CHF'ye mebus adaylığı için başvuranların sayısı 600'ü bulmuş ve başvurular sürmektedir. ${ }^{65} 18$ Ağustos'a kadar toplam başvuru sayısının 1.000'i bulduğu da basına yansımıştır. ${ }^{66}$ Hizmet'in 7 Ağustos'ta İstanbul'dan aldığı habere göre, Gazi Mustafa Kemal ve İsmet Paşalar mebus namzetlerinin başvurularını incelemeye başlamışlardır. ${ }^{67} 9$ Ağustos tarihli ve Ankara kaynaklı bir habere göre de, 3. Meclis'te muhtemelen 310 mebus bulunacaktır. Henüz bütün vilayetlerden bilgi gelmediği için kesin sayı verilememektedir. ${ }^{68}$ Ankara kaynaklı 20 Ağustos tarihli habere göre, mebus seçimi hazırlıkları son noktaya gelmiştir. Dahiliye Vekaleti 1 Eylül tarihinde mebus seçimlerine başlanması için yakında vilayetlere tebligatta bulunacaktır. ${ }^{69}$ Hizmet'in 25 Ağustos Ankara kaynaklı haberine göre, CHF'nin Rum, Ermeni ve Yahudilerden de birer mebus adayı göstereceği kuvvetle muhtemeldir. ${ }^{70}$ İki gün sonraki gazetelerde Yahudilerden Avram Galanti, Ermenilerden Keresteciyan ve Rumlardan da Panciri'nin mebus adayı gösterilecekleri rivayeti aktarılıyor. Hizmet'teki haberin hemen altında bu rivayetin yanlış olduğuna dair bir haber de yer alıyor. ${ }^{71}$ Anadolu Ajansı kaynaklı habere göre, 28 Ağustos akşamı Dolmabahçe'de; reisicumhur, başvekil, BMM reisi ve vekillerin katıldığ 1 bir toplantı yapılmış ve gece yarısından sonraya sarkmıştır. $^{72}$ Nihayetinde 30 Ağustos günü Gazi Mustafa Kemal, Türk Milletine ve mebus

\footnotetext{
${ }^{63}$ Anadolu, 4 Eylül 1927, s. 1.

64 Öztürk 1995b, s. 460, 463-469. Her vilayetin toplam oyu, ilgili vilayetin tüm adaylarında aynidır.

${ }^{65}$ Hizmet, 29 Temmuz 1927, s. 2.

${ }^{66}$ Anadolu, 19 Ağustos 1927, s. 2.

${ }^{67}$ Hizmet, 8 Ağustos 1927, s. 2.

${ }^{68}$ Hizmet, 10 Ağustos 1927, s. 2.

${ }^{69}$ Hizmet, 21 Ağustos 1927, s. 2.

${ }^{70}$ Hizmet, 26 Ağustos 1927, s. 2.

${ }^{71}$ Hizmet, 28 Ağustos 1927, s. 2; Anadolu, 28 Ağustos 1927, s.2.

${ }^{72}$ Hizmet, 30 Ağustos 1927, s. 1.
} 


\section{Nejdet BILGi}

adaylarına birer beyanname yayınlayarak, toplam 311 mebus adayının bulunduğu listeyi de ilan etmiştir. ${ }^{73} \mathrm{Bu}$ arada, 1931 seçimlerinde görüleceği gibi, ne müstakil adaylar için boşluk bırakılmış ne de Gayrimüslim adaylara yer verilmiştir. $\mathrm{Bu}$ da, CHF adaylarının dışında, vilayetlerin çoğunda bağımsız adayın çıkmadığı anlamına gelmektedir. Bağımsız adaylara ilişkin bilgiler çok sınırlıdır ve seçim sonuçlarına göre seçimi kazanmış bağımsız aday bulunmamaktadır.

Müntehib-i sani seçimleri sürerken, Dahiliye Vekaleti de bir taraftan vilayetlerin erkek nüfuslarına göre çıkaracakları mebus sayısını belirlemeye başlamıştır. Nitekim 6 Ağustos'a kadar kaç mebus çıkaracağı belirlenen yerler arasında Manisa da bulunmaktadır. Vilayetin erkek nüfusunun belirtilmediği habere göre, Manisa 9 mebus çıkaracaktır. ${ }^{74}$ Aday listeleri açıklanana kadar, basında kimlerin aday olduklarına dair pek haber çıkmamıştır. Nihayet Gazi'nin 30 Ağustos'ta beyannamelerle birlikte tüm aday listesini açıklaması ile kamuoyu bilgi sahibi olabilmiştir. Ancak sayısı 1000'i geçtiği anlaşılan ve listede yer alamayan aday adaylarının kimler oldukları açıklanmamıştır. $\mathrm{Bu}$ çerçevede Manisa mebus adaylarının listesi de öğrenilmiş oluyordu. 1 ve 2 Eylül tarihli gazetelerde Manisa adayları olarak şu isimlere yer veriliyor: 1Manisa Mebusu Ziraat Vekili Sabri, 2-Erzurum Mebusu Bahri, 3-Manisa Mebusu Doktor Saim, 4-Manisa Mebusu Avukat Mustafa Fevzi, 5-Manisa Mebusu Kemal, 6-Manisa Mebusu Yaşar, 7-Saruhan Vilayeti Cumhuriyet Halk Fırkas1 Heyet-i İdaresinden Çiftçi Kani, 8-Mütekaid Erkan-1 Harbiye kaymakamı erbab-1 ziraatten Manisalı Osman, 9-Alaşehir Cumhuriyet Halk Fırkası Mutemedi Çiftçi Akif Beyler. ${ }^{75}$

Aday listesinin açıklanmasından hemen sonra, Dahiliye Vekaleti vilayetlere bir yazı göndererek, seçimlerin 2 Eylül'de başlamasını ve en kısa zamanda tamamlanmasını istemiştir. Bu sürenin de bir hafta olacağı tahmin edilmektedir. ${ }^{76}$

Manisa'da seçimlerin 2 Eylül'de başlayacağı ve tamamlanacağ 1 da basında yer almıştır. İlgili haberde "Müntehib-i sanilerimizin müttefikan ve kamilen Cumhuriyet Halk Firkamı namzedlerine reylerini istimal edecekleri muhakkakdır" deniliyor. ${ }^{77}$ Manisa seçimleri hakkında en ayrıntılı haber Anadolu'da yer alıyor. Gazetenin muhabir-i mahsusu 3 Eylül'de gönderdiği haberde, öncelikle Dahiliye Vekaleti'nin Manisa'da seçimlerin 2 Eylül'de

\footnotetext{
${ }^{73}$ Hizmet, 31 Ağustos 1927, s. 1; Anadolu, 31 Ağustos 1927, s. 1-3.

${ }^{74}$ Hizmet, 7 Ağustos 1927, s. 2; Anadolu, 7 Ağustos 1927, s. 2.

${ }^{75}$ Vakit, 1 Eylül 1927, s. 2; Hizmet, 1 Eylül 1927, s. 2; 2 Eylül 1927, s. 2; Anadolu, 1 Eylül 1927, s. 2.

${ }^{76}$ Hizmet, 1 Eylül 1927, s. 2.

${ }^{77}$ Anadolu, 2 Eylül 1927, s. 2.
} 
yapılmasını emrettiği belirtiliyor. Fakat, emirle seçim zamanı arasındaki 30 saatlik sürenin yetersiz olduğunu vurgulamayı da ihmal etmiyor. Vilayet kazalarıyla köylerinin çokluğu ve birbirlerine uzaklığı düşünülerek, merkezden biraz müsaade istenmesinin de akla geldiğini, fakat buna gerek kalmadan, Fırka Mutemedi Bahri'nin duruma el koyarak, 10 saat içinde vilayetin en ücra köşelerini bile harekete geçirerek emri duyurduğunu belirtiyor. Nitekim, sabah 8'de Gördes'ten 56 müntehib-i sanin ittifakla firka adaylarını seçtiği, saat 9'da Kasaba/Turgutlu'nun 80 müntehib-i sanisinin yine firka adaylarını ittifakla seçtiği haberlerinin geldiğini belirtiyor. Daha öğle olmadan neredeyse bütün kazaların sonuçlarının geldiğini ilave ediyor. Manisa'da merkez kaza müntehibi sanilerinin belediye dairesinde oy kullandıklarını, toplam 176 müntehib-i saniden birkaç kişi hariç, hepsinin orada olduklarını da belirtiyor. Belediye ve Heyet-i Teftişiye Reisi Abbas Bey'in, kısa bir konuşma yaptıktan sonra, “büyük halaskarımızın” adaylarının kazandığını açıkladığını belirtiyor. Buna göre, Cuma günü saat 15.00 'da Manisa vilayetinin 11 kazasındaki 831 müntehib-i saniden yalnız 20'sinin meşru mazeretlerinden (bazıları İstanbul veya İzmir'de olmalarından, bazılarının da hasta olmalarından) dolayı oy kullanamadıkları ve toplam 811 müntehib-i saninin Gazi’nin adaylarını seçtiğinin anlaşıldığını ilave ediyor. Vali Nusret ve Frrka Mutemed Vekili Bahri’nin, müntehib-i sanilere birer konuşma yaparak seçimi tamamladıklarını ve akşam da Belediye Parkı'nda müntehib-i saniler şerefine bir ziyafet verildiğini ayrıntılarıyla anlatiyor. $^{78}$

Milletvekili mazbatalarına göre, toplam 831 müntehib-i saninin 811’i adaylara oy vermiştir. Adaylara ilçelerden çıkan oy sayılarının dağılımı da aynıdır. ${ }^{79}$ Manisa seçimleriyle aday olarak gösterilen 9 kişinin mebus seçilmeleri böylece kesinleşmiş oluyordu. Nitekim yeni seçilen mebuslardan Bahri, Saim, Kemal ve Osman Nuri, kendilerini tebrik edenlere gazete aracılı̆̆ 1

\footnotetext{
78 “Manisa Vilayeti'nde İntihabat”, Anadolu, 4 Eylül 1927, s. 1. Manisa'nın kazalarındaki mebus seçimleriyle ilgili basına yansıyan bazı haberler de olmuştur. Bunlardan ilki Turgutlu’ya aittir. 2 Eylül'de Belediye Reisi Nuri'nin verdiği bilgiye göre, kazada yüksek tezahüratla gerçekleştirilen seçimde, 80 müntehib-i sani bütünüyle isbat-1 vücut etmiş ve firka adaylarını ittifakla seçmişlerdir. Hizmet, 4 Eylül 1927, s. 2. Demirci kazasında da seçim 2 Eylül günü müntehib-i sanilerden 63'ünün katılımıyla gerçekleşmiştir. 1 müntehib-i sani ticaret maksadıyla İstanbul'da bulunduğu için seçime katılamamıştır. 63 müntehib-i sani, müzik eşliğinde, Gazi'nin süslenmiş resmine de saygı göstererek oy kullanmıştır. Rüşdü Ertuğrul, "Demirci Haberleri”, Hizmet, 8 Eylül 1927, s. 3.

79 https://www.tbmm.gov.tr/eyayin/GAZETELER/WEB/MAZBATALAR/TBMM/d03/SM_502 _1_3.pdf; https://www.tbmm.gov.tr/eyayin/GAZETELER/WEB/MAZBATALAR/TBMM/ d03/SM_734_1_3.pdf; https://www.tbmm.gov.tr/eyayin/GAZETELER/WEB/MAZBATALAR /TBMM/d03/SM_607_1_3.pdf.
} 


\section{Nejdet BILLGI}

ile teşekkür etmişlerdir. ${ }^{80}$

Seçimlerin sonuçlanması dolayısıyla Gazi Mustafa Kemal de vatandaşlara hitaben bir teşekkür açıklaması yapmıştır. "İntihabat neticesinde Cumhuriyet Halk Firkası namına takdim etdiğim namzedler memleketin her tarafinda aziz vatandaşlarımın müttefikan umumi tasvib ve intihabına mazhar oldu" seklinde başlayan teşekkürde, sonucun önceki uygulamaların onayı olduğu belirtilerek ve "vatandaşlarıma atiyen yeni muvaffaklyetler için itimadımızın kavi bir halde bulunduğunu temin ederim" diyerek minnettarlığını dile getiriyor. ${ }^{81}$

\section{Müntehib-i Sani (İkinci Seçmen) Seçimleri}

Serbest Cumhuriyet Fırkası ve başka bazı firkaların kurulması tecrübesinin üzerinden yaklaşı iki ay geçtikten sonra, parlamentonun yenilenmesi gündeme geldi. Bu yaklaşık iki aylık dönem, aynı zamanda Gazi’nin yurtiçi gezileriyle bazı gözlemler yapma firsatı bulduğu bir dönemdir. Aslında seçimlerin olağan olarak yapılmasına yaklaşık 7 ay bulunmaktadır. Buna rağmen Gazi, 1931 genel seçimleri için 4 Mart 1931 tarihinde CHF grup başkanlığına bir takrir vererek, CHF'ye mensup mebusların seçimlerini yenilemelerini uygun gördüğünü belirtti. ${ }^{82}$ Takrir üzerine çıkan haberlerde, mebus maaşlarının 500'den 350 liraya indirileceği, seçimlere derhal başlanacağ 1 ve takririn 5 Mart günü TBMM'de görüşüleceği yazıldı. ${ }^{83}$ TBMM Başkanı Kazım da konuyla ilgili verdiği mülakatta, maaş indirmeyi Gazi'nin teklif ettiğini, yeni seçimlerin yine iki dereceli olacağını belirtti. ${ }^{84}$ Nitekim 5 Mart günü yapılan görüşmelerde 270 oyla ve ittifakla seçimlerin yapılmasına karar verildi. $^{85} \mathrm{Bu}$ çerçevede mebus maaşlarının indirilmesinin gerçekleştiği, Anayasa'da 18 olan seçme yaşının 21 olması için teklif hazırlandığı da haberler arasında yer ald1. ${ }^{86} \mathrm{~K} ı$ sa bir süre sonra seçmen yaşının indirilmesinden vazgeçildiği anlaşılıyor. ${ }^{87} \mathrm{Bu}$ arada İstanbul Kadınlar Birliği'’nin de bir teklifte bulunarak, kadınlara da seçme hakkının verilmesini isteyeceği haberlerde yer aldıysa da ${ }^{88} 1931$ genel seçimleri sürecinde bu gerçekleşmedi.

Seçim kararının alınmasıyla birlikte başlayan süreçte, Manisa vilayetinin

\footnotetext{
${ }^{80}$ Hizmet, 12 Eylül 1927, s. 2.

${ }^{81}$ Anadolu, 8 Eylül 1927, s. 1.

${ }^{82}$ Anadolu, 5 Mart 1931, s. 1.

${ }^{83}$ Anadolu, 5 Mart 1931, s. 1-2.

${ }^{84}$ Anadolu, 5 Mart 1931, s. 4.

${ }^{85}$ Anadolu, 6 Mart 1931, s. 2.

${ }^{86}$ Anadolu, 8 Mart 1931, s. 2.

${ }^{87}$ Anadolu, 10 Mart 1931, s. 2.

${ }^{88}$ Anadolu, 5 Mart 1931, s. 1.
} 
9 mebus çıkaracağının belirlendiği, CHF vilayet idare heyeti azaları ile bazı firka seçmenlerinin, müntehib-i sani seçilecekleri tespit etmek için kazalara gittikleri haberleri çıktı. Ayrıca CHF teşkilatının müntehib-i sanileri münevver ve inkılapçı zümreden seçmek için, özellikle özen ve çaba gösterdiği de vurgulandı. ${ }^{89} 6$ Mart'ta yayımlanan bir haberde, mebus seçimi hazırlıklarına başlanması için Dahiliye Vekaleti'nden ilgili birimlere emir verildiği belirtilmektedir. ${ }^{90}$ Yeni mebus adayları listesinin Reisicumhur tarafından 20 Nisan'da ilan edileceği haberleri de yayımlandı. ${ }^{91} \mathrm{Bu}$ arada bazı kimselerin yeni seçimlerde müstakilen aday olabileceklerine dair haberler de çıktı. ${ }^{92} 3$ Nisan tarihli bir habere göre, seçimler sonucunda TBMM'ye bu dönem 317 mebus seçilmiş olacaktır. $\mathrm{Bu}$ arada mebusluk için başvuranların sayısı da 1.300'ü bulmuştur. $^{93} 15$ Nisan'da CHF Katibiumumiliği bir tebliğ yayınlayarak, 22 vilayette 30 kadar mebusluk için CHF'nin aday göstermeyeceği, buralardan müstakil mebusların aday olacaklarını duyurdu. $\mathrm{Bu} 22$ vilayetten birisi de Manisa'dır. ${ }^{94}$ Dahiliye Vekaleti 19 Nisan'da valiliklere bir tebligat göndererek mebus seçimlerinin 24 Nisan Cuma günü, ülkenin her yerinde başlayacağını bildirmiştir. Benzer bir bilgi de CHF tarafindan teşkilatlara gönderilmiştir. ${ }^{95}$ Gazi, 20 Nisan'da yayınladığı Millete Beyanname ile halka, "inkılap ve itila mesaimize devam edebilmek için itimadınızı talep etmek üzere yüksek huzurunuza çıklyoruz" diyerek, CHF mebus listesine destek istedi. ${ }^{96}$ Müntehib-i sanilere hitaben yayınladığ 1 beyannamede, "firkamızın millete arzettiği esas noktalar dahilindeki mesai ve faaliyetin bizim fikrimize ve görüşümüze iştirak etmeyen millet vekilleri tarafından tahlil ve tenkit edilmesini iltizam ediyoruz" diyerek,15 Nisan 1931 tarihinde CHF Riyaset Divanı kararının gerekçesini açıklamış oldu. Beyannamenin sonunda da, CHF'ye mensup olmayan adaylara da oy verilmesini istiyor ve şöyle tamamliyor: "Açık bıraktığım yerler için hiçbir şahsiyet lehinde veya aleyhinde herhangi bir telkinim yoktur ve olmayacaktır. Açık yerlere namzetliklerini koyacaklar hakkında vicdani kanaatinize göre rey vermek hassaten rica ettiğim husustur." ${ }^{97}$ Gazi’nin bu tutumunu, Serbest Firka tecrübesinin bir eseri olarak değerlendirmek yanlış olmasa gerektir.

\footnotetext{
${ }^{89}$ Hizmet, 23 Mart 1931, s. 3.

${ }^{90}$ Anadolu, 6 Mart 1931, s. 1.

${ }^{91}$ Anadolu, 9 Mart 1931, s. 2.

${ }^{92}$ Anadolu, 13 Mart 1931, s. 2.

${ }^{93}$ Anadolu, 3 Nisan 1931, s. 2.

${ }^{94}$ Anadolu, 16 Nisan 1931, s. 1-2.

${ }^{95}$ Anadolu, 20 Nisan 1931, s. 1-2.

${ }^{96}$ Anadolu, 21 Nisan 1931, s. 1, 4.

${ }^{97}$ Anadolu, 21 Nisan 1931, s. 1. Ayrica bkz. ABE 2009, s. 116-117.
} 


\section{Nejdet BILGi}

Manisa bağlamında seçimlere ilişkin ilk haberde, 8 Mart'ta Akhisar'da seçim hazırlıklarına başlandığı, defterlerin düzenlenmesine çalışıldığ belirtilmektedir. $^{98} 10$ Mart tarihli bir haberde, Manisa'ya seçimlerin yenilenmesine ilişkin Dahiliye'den emir geldiği, Vali Fuat'ın seçim hazırlıkları için ilgililere tebligatta bulunduğu, belediyenin de seçim hazırlıklarına başladığg 1 ve defterleri kısa zamanda hazırlayarak seçim gününü bekleyeceği belirtiliyor. ${ }^{99}$ Nitekim 15 Mart'ta Manisa'da seçim defterleri hazırlanarak teftiş heyetine verilmiştir. ${ }^{100}$ Akhisar'da ise defterlerin düzenleme işinin tamamlanarak askıya çıkarıldığı, sürenin bitiminde seçime başlanmak üzere hazırlı̆̆ın tamamlandığ 1 bildirilmektedir. ${ }^{101} 23$ Mart'taki bir haberde ise, Akhisar'da defterlerin köy ve mahallelere asıldığı ve kontrol edildiği belirtilmektedir. ${ }^{102}$ Aynı gazetede, Manisa'nın 9 mebus çıkaracağının anlaşıldığı, Halk Fırkası'nın vilayet idare heyeti azalarıyla bazı fırka seçmenlerinin, müntehib-i sani seçileceklerin tesbiti için kazalara gittikleri, müntehib-i sanilerin münevver ve inkılapçı zümreden seçilmesi için itina ve çaba gösterildiği belirtiliyor. ${ }^{103} \mathrm{Bu}$ arada Manisa'dan Orta Mektep Müdürü Cenap Refik'in mebusluk için aday olanlar arasında adı geçtiği de naklediliyor. ${ }^{104}$ Anadolu gazetesi, Akhisar'da müntehib-i sani seçimine 5 Nisan günü başlanacağ 1 haberini veriyor. ${ }^{105} 6$ Nisan tarihli haberde, Kırkağaç Belediye Hekimi Hakkı Halil'in CHF Umumi Katipliği'ne başvurarak, kendi bölgesinden, yani Manisa'dan mebusluk için aday gösterilmesini istediği belirtilmektedir. ${ }^{106}$ Soma'da 5 Nisan'da bütün seçim dairelerinde müntehib-i sani seçimine başlandığ 1 belirtilmektedir. ${ }^{107}$ Anadolu gazetesinin verdiği bilgilere göre, Manisa vilayetinin her tarafinda 4 Nisan sabahı müntehib-i sani seçimlerine başlanmıştır. Manisa'da sabahleyin önde müzika olduğu halde, teftiş heyetleri ve halktan birçoklarını taşıyan otomobiller seçim dairelerine giderek işe başlamışlardır. ${ }^{108} 8$ Nisan'da gönderilen bir haberde, Manisa'da müntehib-i sani seçimlerinin 3. Günde yarıdan fazlasının oylarını kullandıkları ve seçimin hararetle devam ettiği, Gördes ve Kırkağaç’ta ise tamamlandı̆̆ 1

\footnotetext{
${ }^{98}$ Anadolu, 9 Mart 1931, s. 2.

${ }^{99}$ Anadolu, 10 Mart 1931, s. 1.

${ }^{100}$ Anadolu, 16 Mart 1931, s. 2.

${ }^{101}$ Anadolu, 16 Mart 1931, s. 4.

${ }^{102}$ Anadolu, 23 Mart 1931, s. 4.

${ }^{103}$ Anadolu, 23 Mart 1931, s. 5.

${ }^{104}$ Anadolu, 24 Mart 1931, s. 2.

${ }^{105}$ Anadolu, 5 Nisan 1931, s. 2.

${ }^{106}$ Anadolu, 6 Nisan 1931, s. 1. Daha sonra yapılan açıklamada Halil Hakkı'nın halen belediye doktoru olmadığı ve Manisa vilayet umumi meclis azası olduğu belirtiliyor. Anadolu, 10 Nisan 1931, s. 3.

${ }^{107}$ Anadolu, 6 Nisan 1931, s. 2.

${ }^{108}$ Anadolu, 7 Nisan 1931, s. 2.
} 
belirtiliyor. ${ }^{109}$ Ertesi günkü gazetede, Kırkağaç merkezde seçimin bittiğini, köylerde ise devam ettiğini belirtiyor. ${ }^{110}$ Akhisar'da 12 Nisan'da seçimin bittiği ve halkın müttefikan oylarını CHF adaylarına verdikleri belirtiliyor. ${ }^{111}$ Yine 12 Nisan'da Manisa merkez kazası ile Kırkağaç, Gördes, Kula, Alaşehir, Demirci, Kasaba kazalarında müntehib-i sani seçimi tamamlanmış ve bütünüyle Halk Fırkası adayları kazanmıştır. Manisa merkez kazasındaki 8 seçim dairesine ait sandıklar, hava muhalefetine rağmen merasimle Belediye dairesine getirilmiştir. CHF Katibiumumiliği, oylarını fırka adaylarına verdikleri için Manisa merkez kaza birinci müntehiplerine telgrafla teşekkür etmiştir. Ayrıca Vali Fuat'ın, seçim işlerini yakından takip ederek kanunsuz işlem yapılmamasına dikkat ettiği de vurgulanmaktadır. ${ }^{112}$ Vali Fuat'ın 13 Nisan'da verdiği bilgilere göre, Manisa vilayetinin her tarafında müntehib-i sani seçimleri tamamlanmış ve CHF adayları kazanmışlardır. Halkın \%75'i seçimlere katılmış ve kalan \%25'i de son yağmurlardan dolayı seçim merkezlerine gelemedikleri için, oylarını kullanamamışlardır. Vali, halkın siyasi haklarını kullanmakta gösterdiği ilgiyi takdirle karşılamaktadır. ${ }^{113} \mathrm{Bu}$ seçimlerde dikkati çeken husus, basında müntehib-i sayısına bu ilk aşamada hiçbir şekilde değinilmemesi olmuştur. Ancak dönem milletvekillerinin mazbatalarında toplam müntehib-i sani sayısının 893 olduğu belirtilmektedir. ${ }^{114}$ Hatta döneme ait milletvekili biyografilerini içeren kitapta da hemen bütün özgeçmişlerde alınan oy miktarı belirtilmemektedir. ${ }^{115}$

\section{Mebus (Milletvekili) Seçimleri}

Müntehib-i sani seçimlerinin tamamlanmasıyla birlikte mebus adayları gündeme geldi. Çok geçmeden Gazi tarafindan belirlenen CHF'nin aday listeleri, 20 Nisan'da yayınlandı. Buna göre, Manisa mebus adayları şöyledir: 1Manisa Mebusu Kani, 2-Manisa Mebusu Mustafa Fevzi, 3-Manisa Mebusu Osman, 4-Mardin Mebusu Yakup Kadri, 5-Cebelibereket Mebusu Sabri, 6İzmir Ticaret Odası Katibiumumisi Turgut, 7-Esbak Adliye Vekili Avukat Refik Şevket, 8-Manisa'nın Saruhanlı Köyü’nden Niflizade Çiftçi Halil, 9-Müstakil

\footnotetext{
${ }^{109}$ Anadolu, 9 Nisan 1931, s. 2.

${ }^{110}$ Anadolu, 10 Nisan 1931, s. 3.

${ }^{111}$ Anadolu, 13 Nisan 1931, s. 2.

${ }^{112}$ Anadolu, 14 Nisan 1931, s. 1.

${ }^{113}$ Anadolu, 15 Nisan 1931, s. 2.

114 https://www.tbmm.gov.tr/eyayin/GAZETELER/WEB/MAZBATALAR/TBMM/d04/SM_590 1_4.pdf; https://www.tbmm.gov.tr/eyayin/GAZETELER/WEB/MAZBATALAR/TBMM/d04 /SM_371_1_4.pdf.

${ }^{115}$ Çoker 1996, s. 423-434.
} 


\section{Nejdet BILGi}

aday için açık bırakılmıştır. ${ }^{116} 22$ Nisan tarihli bir haberde, Manisa'dan müstakil aday olarak Hadi'nin adı geçmektedir. ${ }^{117}$ Ertesi günkü bir haberde ise, Manisa'dan müstakil namzetliğini koyan Sitkı Şükrü’nün propaganda yapmaya başladığı belirtilmektedir. ${ }^{118} 23$ Nisan tarihli Hizmet'te Manisa ziraatçılarından Evrenoszade Haydar ve Baytar Hadi'nin Manisa müstakil mebusluğu için aday oldukları, birkaç kişinin daha başvurmasının beklendiği belirtilmektedir. Ayrıca Sıtkı Şükrü'nün evvelce Halk Fırkası'na başvurup aday olmak istediği için, müstakil aday olamayacağ 1 da vurgulanmaktadır. ${ }^{119}$ Aynı gazetenin haberine göre, 22 Nisan akşamı Manisa Valisi Fuat, eski Belediye Reisi Külahdaşzade Rıza, Halk Fırkası Reisi, Bağcılar Bankası Müdürü Kenan, Belediye Reisi Rıza ile kaza idare heyetinin toplanarak, Manisa'dan seçilmesi gereken bir müstakil mebus için görüşmüşler ve sonuçta kaza CHF teşkilatının ayrı ayrı görüşlerine başvurulmasını kararlaştırmışlardır. ${ }^{120} 24$ Nisan tarihli haberde, Manisa'da müstakil adaylar arasında çiftçi Evrenoszade Haydar ve Baytar Hadi'nin adı geçtiği belirtildikten sonra, "Manisa namına namzedliğini koyan Baytar Sitkı Şükrü Bey daha evvel namzedliğinin konması için Halk Fırkası'na da müracaat ettiği için teftis heyeti bu zatın müstakil namzedliğini muteber tutmamaktadır" denilmektedir. ${ }^{121}$

Nihayetinde 24 Nisan'da yapılan mebus seçimlerinde, Manisa'dan boş bırakılan yer için Başvekil İsmet Paşa seçilmiştir. ${ }^{122}$ Hizmet gazetesi bir-iki gün sonraki haberinde, İsmet Paşa'nın henüz Manisa veya Malatya mebusluğu için karar vermediğini belirtirken ${ }^{123}$ Son Posta gazetesi, İsmet Paşa'nın Manisa müntehib-i sanilerine teveccühleri için teşekkür ettiğini ve Manisa'dan seçilmesinin doğru olmayacağını ve ayrıca Reisicumhur tarafından "verilen vecheye tevafuk etmediğini” söylediğini yazmıştır. ${ }^{124}$

Manisa seçimleri, 24 Nisan saat 11.00 'de bütünüyle sonuçlanmıştır.

\footnotetext{
${ }^{116}$ Anadolu, 21 Nisan 1931, s. 4; Son Posta, 22 Nisan 1931, s. 3. Ayrica bkz. ABE 2009, s. 123.

${ }^{117}$ Anadolu, 22 Nisan 1931, s. 1.

118 Son Posta, 23 Nisan 1931, s. 3.

${ }^{119}$ Hizmet, 23 Nisan 1931, s. 1.

${ }^{120}$ Hizmet, 23 Nisan 1931, s. 1.

${ }^{121}$ Son Posta, 24 Nisan 1931, s. 3.

122 Anadolu, 26 Nisan 1931, s. 1. Son Posta'nın haberine göre, Manisa müntehib-i sanileri aralarında anlaşarak, müstakil mebusluğa İsmet Paşa'yı seçmişlerdir. Haberin devamında, "Manisa müntehib-i sanilerinin bu intihabı neden yaptzkları izah edilemiyor. Şimdi İsmet Paşa Malatya'dan da intihab edildiği cihetle iki mıntıkadan birini tercih etmek karşısındadırlar. Fakat Milli Mücadele'nin başlangıcından beri Malatya'yı temsil ettiği için intihap dairesini değiştirmesine ihtimal verilemez" denilmektedir. "İzmir'de Rey Alamayan Müstakiller", Son Posta, 26 Nisan 1931, s. 3.

${ }^{123}$ Hizmet, 28 Nisan 1931, s. 3.

124 “Başvekilin Telgrafı Manisa Müntehib-i Sanilerini Üzdü”, Son Posta, 28 Nisan 1931, s. 3.
} 
Anadolu'nun haberine göre, 893 müntehib-i saniden oylamaya katılan $855^{\prime} \mathrm{i}$ tamamen CHF adaylarına oy vermişlerdir. Açık bırakılan bir müstakil mebusluk için müntehib-i saniler arasında uzun değerlendirmeler yapıldıktan sonra, oylamaya katılanlardan 7'si hariç, tamamı oylarını İsmet Paşa'ya vermişlerdir. Müstakil aday Baytar Sıdkı Şükrü 5 ve İzmir Esnaf ve Ahali Bankası Meclis-i İdare Reisi Mustafa Muharrem ise 2 oy almışlardır. Bu durumda; İsmet Paşa, Kani, Osman, Mustafa Fevzi, Sabri, Yakup Kadri, Refik Şevket, Turgut ve Halil Beyler Manisa mebusu seçilmişlerdir. ${ }^{125} 27$ Nisan 1931 tarihli Milletvekili mazbatalarına göre, Manisa'da toplam 893 müntehib-i sani bulunmaktadır. Adaylardan Kâni, Osman, Mustafa Fevzi, Yakup Kadri, Sabri, Turgut, Refik Şevket, Niflizade Halil Beyler ve İsmet Paşa'ya 874'er oy verilmiştir. Baytar Sttkı Şükrü’ye 7, Mustafa Muharrem'e 4 ve Alaşehirli Etem Beyzade Ömer Lütfü'ye 1 oy çıkmıştır. ${ }^{126}$

Dahiliye Vekaleti de yayınladığı tebliğ ile 24 Nisan sabahı başlayan seçimlerin aynı gün tamamlandığını ve müstakil aday gösterilen 22 vilayetten İstanbul, Samsun ve Tekirdă̆ı'ndan kimse seçilmemiş, Manisa'dan da İsmet Paşa'nın seçilmiş olduğunu duyurmuştur. ${ }^{127}$

\section{Sonuç}

Cumhuriyet döneminin ilk yıllarına ilişkin her çalışmada olduğu gibi bu çalışmada da en fazla başvurulan kaynak grubunu basın oluşturmaktadır. Özellikle seçimler veya siyasi hayat üzerine çalışmalarda bu kaçınılmaz bir durumdur. Çünkü 1950 öncesi seçimlerine ilişkin elde ne istatistiki ne de arşiv nitelikli veri bulunmaktadır. Kontrollü bir yönetim tarzının basındaki yansıması, olabildiğince az ve sınırlı bilgidir. Üstelik konu birkaç ay yayınlanmış yerel bir gazeteden başka süreli yayının bulunmadığı Manisa olunca, veri derlemek daha da zorlaşmaktadır. Yakınında gelişmiş bir bölge basını bulunan İzmir olmasaydı, belki de ulaşabildiğimiz bu sınırlı bilgiler de olmayacaktı.

Özellikle İzmir basınından devşirilen verilerle Manisa'da Cumhuriyet'in ilk üç genel seçimi hakkında bir nebze de olsa bilgi oluşturulmuştur. $\mathrm{Bu}$

\footnotetext{
${ }^{125}$ Müdüroğlu, "Manisa'da”, Anadolu, 26 Nisan 1931, s. 2.

126 https://www.tbmm.gov.tr/eyayin/GAZETELER/WEB/MAZBATALAR/TBMM/d04/SM 734 1 4.pdf; https://www.tbmm.gov.tr/eyayin/GAZETELER/WEB/MAZBATALAR/TBMM/d04 ISM_733_1_4.pdf.

127 "Tebliğler", Anadolu, 26 Nisan 1931, s. 6. Ertesi günkü bir haberde, Manisa'da açık bırakılan bir mebusluk için aday olan Ali İsmail Bey'in kendisini seçmeyen müntehiblere, "ergeç beni intihap edeceksiniz" dediği ve aklını oynattı̆̆ belirtilmektedir. Anadolu, 27 Nisan 1931, s. 2. $\mathrm{Bu}$ arada $\mathrm{CHF}$ tarafından müstakillere oy verilmemesi hakkında hiçbir gizli emir verilmediği belirtilerek, Adana'dan Ali Münif, İzmir'den Halil'in seçildikleri örnek olarak gösteriliyor. Anadolu, 28 Nisan 1931, s. 2.
} 


\section{Nejdet BILGi}

çerçevede 1923 seçimleriyle ilgili yaygın kanaat olarak belirtilen, tek parti döneminin en özgür seçimi yorumunun Manisa için de geçerli olduğu söylenebilir. Henüz CHF'ye dönüşmemiş Müdafaa-i Hukuk yapısıyla gerçekleştirilen seçimin, Manisa'da milletvekili adayları arasında büyük bir rekabete sahne olduğu anlaşılmaktadır. Ancak bu rekabetin seçmenler nezdinde değil, aday gösterilme aşamasında Müdafaa-i Hukuk Grubu liderleri nezdinde olduğunu görmek gerekir. Yine bu aşamada yerel yöneticilerin ne kadar belirleyici veya lider kadroya nüfuz edici olduklarını Yakup Kadri örneğinde görmek mümkündür.

1927 genel seçimi dönemin en kontrollü seçimidir. Şeyh Sait ayaklanması, Takrir-i Sükûn, İzmir suikasti girişimi ve yargılamaları gibi, dönemin en kritik olaylarından sonra yapılmış olmasının rolü büyük olsa gerektir. Kimlerin aday olduklarından, adayların belirlenme sürecinden, seçimlerin yapılış şekline kadar, tüm sürecin iktidar partisi CHF yönetiminin mutlak denetiminde olduğu bir seçimdir. Seçim parti yönetiminin belirlediği isim listelerinin onaylanmasından başka alternatifin bulunmadığı bir tarzda gerçekleşmiştir. Dolayısıyla öncesindeki 1923 ve sonrasındaki 1931 seçimlerinden bir hayli geridedir. Adayların aldıkları oyların ikinci seçmen sayısıyla aynı olması da bunu göstermektedir.

1931 genel seçimi de, her olay gibi öncesindeki gelişmelerden etkilenmiştir. 1930 yılında girişilen SCF tecrübesinin bu seçim üzerinde belirleyiciliği fark edilmektedir. En azından adaylık sürecinin 1927'ye göre daha açık olması, sınırlı da olsa bağımsız adaylara yer verilmesi önemlidir. $\mathrm{Bu}$ durum SCF ile başlayan ve kısa süren serbest seçim kapısının tam kapatılmadığını göstermektedir. Manisa özelinden bakıldığında listelere konulan ve seçilen adayların, devletçi uygulamalara geçildiği bir dönemde, eleştirel ve liberal isimler barındırması da dikkat çekmektedir. Fevzi Lütfi ve Refik Şevket isimleri, bu bağlamda anılabilir. Dolayısıyla SCF deneyiminin hem CHF listelerinin şekillenmesinde ve hem de sınırlı sayıda bağımsız adaya kapı aralanmasında belirleyici olduğu söylenebilir. 
Tek Parti Yönetimi Kurulurken Manisa’da Genel Seçimler (1923-1931)

\section{KAYNAKLAR}

\section{Gazeteler}

Akşam (İstanbul, 1923).

Anadolu (İzmir, 1927, 1931).

Hakimiyet-i Milliye (Ankara, 1923).

Hizmet (İzmir, 1927, 1931).

Saruhan (Manisa, 1923).

Son Posta (İstanbul, 1931).

Tanin (İstanbul, 1923).

Türk Sesi (İzmir, 1923).

Vakit, (İstanbul, 1923, 1927).

\section{Gazete Yazıları}

1931, s. 3.

"Başvekilin Telgrafı Manisa Müntehib-i Sanilerini Üzdü”, Son Posta, 28 Nisan

“İzmir'de Rey Alamayan Müstakiller”, Son Posta, 26 Nisan 1931, s. 3.

"Manisa Vilayeti'nde İntihabat", Anadolu, 3 Ağustos 1927, s. 1-2.

“Manisa Vilayeti'nde İntihabat", Anadolu, 4 Eylül 1927, s. 1.

“Manisa'da İntihabat”, Ahenk, 22 Haziran 1339, s. 3.

“Manisa'da İntihabat", Saruhan, 30 Haziran 1923.

"Soma'da İntihabat", Hizmet, 10 Ağustos 1927, s. 3.

“Tebliğler”, Anadolu, 26 Nisan 1931, s. 6.

Doğan, "Soma Mektubu İntihabat Hareketleri", Hizmet, 2 Ağustos 1927, s. 2.

Er-Tunç, "Salihli Haberleri”, Hizmet, 7 Ağustos 1927, s. 3.

Müdüroğlu, "Manisa'da", Anadolu, 26 Nisan 1931, s. 2.

Rüşdü Ertuğrul, “Demirci Haberleri”, Hizmet, 8 Eylül 1927, s. 3.

Rüşdü Ertuğrul, “Demirci Muhabirimizden”, Hizmet, 27 Temmuz 1927, s. 3.

Uygur Tekin, “Salihli Haberleri”, Anadolu, 8 Ağustos 1927, s. 2.

Zeynel Besim, “Müstakil Namzedler”, Hizmet, 28 Temmuz 1927, s. 1.

\section{Kitap, Tez ve Makaleler}

ABE 2009

Çoker 1996

Erdoğan 2000

Güneş 1991
Atatürk’ün Bütün Eserleri, C. 25, Kaynak, İstanbul.

Fahri Çoker, Türk Parlamento Tarihi TBMM IV. Dönem 19311935, II. Cilt, TBMM Vakfi, Ankara.

Melda Erdoğan, 1923 Seçimleri, Basılmamış Yüksek Lisans Tezi, Anadolu Üniversitesi Sosyal Bilimler Enstitüsü, Eskişehir.

İhsan Güneş, "1923 Seçimlerinde Oylar Nasıl Kullanıldı?”, AÜ Siyasal Bilimler Fakültesi Dergisi, C. XLVI/1-2 (Ocak-Haziran 1991) s. 253-264. 


\section{Nejdet BILGi}

Karaosmanoğlu 1984 Yakup Kadri Karaosmanoğlu, Politikada 45 Yll, İstanbul.

Olgun 2011

Kenan Olgun, “Türkiye'de Cumhuriyetin İlanından 1950’ye

Genel Seçim Uygulamaları", Atatürk Araştırma Merkezi

Dergisi, XXVII/79 (Mart 2011), Ankara, s. 1-36.

Öztürk 1995a Kâzım Öztürk, Türk Parlamento Tarihi TBMM - II. Dönem 1923-1927, III. Cilt, TBMM Vakfı, Ankara.

Öztürk 1995b Kazım Öztürk, Türk Parlamento Tarihi TBMM III. Dönem 1927-1931, TBMM Vakfi, Ankara.

Uyar 1999 Uyar, Hakkı, "Tek Parti Döneminde Seçimler”, Toplumsal Tarih, 11/64 (Nisan 1999), s. 21-31.

\section{Internet Sayfaları}

https://www.tbmm.gov.tr/eyayin/GAZETELER/WEB/MAZBATALAR/TBMM/d02/SM 3721 2.pdf.

https://www.tbmm.gov.tr/eyayin/GAZETELER/WEB/MAZBATALAR/TBMM/d04/SM_590_1_ 4.pdf.

https://www.tbmm.gov.tr/eyayin/GAZETELER/WEB/MAZBATALAR/TBMM/d04/S M_371_1_4.pdf.

https://www.tbmm.gov.tr/eyayin/GAZETELER/WEB/MAZBATALAR/TBMM/d04/SM_733_1_ 4.pdf.

https://www.tbmm.gov.tr/eyayin/GAZETELER/WEB/MAZBATALAR/TBMM/d03/SM_607_1_ 3.pdf.

https://www.tbmm.gov.tr/eyayin/GAZETELER/WEB/MAZBATALAR/TBMM/d03/SM_502_1_ 3.pdf.

https://www.tbmm.gov.tr/eyayin/GAZETELER/WEB/MAZBATALAR/TBMM/d03/SM 734 1 3.pdf.

\section{SUMMARY}

As in every study focusing on the early years of the Turkish Republic, most of the data in this study was taken from the press. This is especially inevitable when a study investigates the elections or the political context of the era, and that is due to the lack of statistical and archived data on the elections between 1923 and 1931. Newspapers of the period do not bear sufficient information either. A heavily controlled governmental style also limits the information flow of the press. For the observed period, there was only one local newspaper of Manisa, which was published just for a couple of months. The reason for is that, Manisa was under İzmir's sphere of influence in terms of the press. That is why the bulk of this study's resources consist of İzmir newspapers of the election periods, as well as some national newspapers of the era.

Established in 1920, the First Grand National Assembly was renewed by election after the Turkish War of Independence. Groundwork for the election was put into place upon the renewal decision in April 1923. This election marks the beginning of the 
single-party period. Even though the majority of the second group in the assembly was dismissed, it is regarded as the most freely held election of the era. Individuals with extensive local influence played a significant role in determining the candidates for the 1923 deputy election in Manisa. Spanning over three months on a national level, elections in Manisa was completed in only five weeks. Manisa sent nine deputies to the Assembly with this election.

Prior to the establishment of CHF (Republican People’s Party), the 1923 deputy elections was held with Müdafaa-i Hukuk Cemiyeti (Association for Defence of National Rights). Manisa witnessed a great deal of competition amongst the candidates. However, the competition was not about the elections themselves, but the selection of candidates among the leaders of Müdafaa-i Hukuk.

1927 was held in a heavily oppressive setting where the opposition parties, organizations, political figures and the press was subdued due to the Takrir-i Sükun (Law for the Maintenance of Public Order). 1927 deputy election was held only with the CHF candidates, and it was more of an acknowledgment than an election. The "secondary voter" election was concluded on August 10, 1927, and the deputy elections on September 8. Unlike the National election, Manisa started and concluded the its deputy election on September 2. Once again, nine deputies were elected in Manisa. As there were no alternatives all candidates received the same number of votes, which was the number of secondary voters.

In the first election, a total of 831 secondary voters were elected in Manisa. Among them, 811 voted in the deputy elections, and 20 did not cast a vote. Therefore, all of the elected deputies received 811 votes. In terms of democratic credibility, 1927 deputy elections fall behind both the 1923 elections, and the following 1931 elections. Indeed, Gazi Mustafa Kemal interpreted the election results as the approval of previous decisions and practices.

The general election of 1931 was held seven months early. After the election decision, candidate numbers for the provinces were determined. CHF reserved 30 seats for independent candidates in 22 out of 63 constituencies. Eight candidates from CHF was running in Manisa, which had a total of nine seats, and one spot was reserved for an independent candidate. Seven nominees competed for the independent spot. The "secondary voter" elections in Manisa were held between April 4 and 13. Deputy election was held on April 24, same as the rest of the country. Eventually, secondary voters elected eight CHF candidates, and İsmet Pasha for the independent seat. Therefore, the independent spot was also occupied by a CHF member. 1931 elections carry the marks of SCF (Liberal Republican Party), which was both founded and dissolved in 1930. However, most of the 30 seats reserved for independent candidates remained empty as it did in Manisa. Nevertheless, 1931 deputy elections offered much more action space to the voters compared to the 1927 election.

1931 general election was influenced greatly by the recent developments. The failed attempt of SCF in 1930 surely affected the outcome of this election. At the very least, the candidacy process was much clearer compared to 1927 and albeit limited, a number of seats were given to the independent candidates. This meant the free election 
window opened by the short-lived SCF, was still not fully closed. As for Manisa, the nominees and the elected candidates included a number of critical voices and liberal figures, which was quite interesting in the increasingly statist environment of the era. Fevzi Lütfi and Refik Şevket can be counted in this context. Therefore, it is safe to say that the SCF experience had a determining effect on both shaping the CHF lists and opening up seats for the independent candidates.

Although there were some differences, 1923, 1927 and 1931 general elections were all two-stage elections. The limited options in the 1931 election was not enough to change the results. The single-party rule was thus institutionalized. This study is the first attempt to portray the first three general elections and the election process in Manisa during the early years of the Turkish Republic 